\title{
Diversity and Distribution of Dragonflies in Bukit Timah Nature Reserve, Singapore
}

\author{
Y. Cai ${ }^{1}$ Y.P.Q. $\mathrm{Nga}^{1,2}$ \& R.W.J. Ngiam ${ }^{3}$ \\ ${ }^{1}$ National Biodiversity Centre, National Parks Board, \\ 1 Cluny Road, 259569 Singapore \\ cai_yixiong@nparks.gov.sg \\ ${ }^{2}$ School of Biological Sciences, Nanyang Technological University, \\ 60 Nanyang Drive, 637551 Singapore \\ ${ }^{3}$ Central Nature Reserves, National Parks Board, \\ 1 Cluny Road, 259569 Singapore
}

\begin{abstract}
Biodiversity baselines were established for dragonflies (Insecta: Odonata) of Bukit Timah Nature Reserve, Singapore, based on quantitative and qualitative samplings. Surveys were conducted from December 2014 to February 2016. Hydrological, physicochemical parameters and habitats were analysed to understand the main drivers structuring the dragonfly community. A total of 829 odonate specimens were recorded during the quantitative sampling, comprising 36 species of 28 genera in 11 families. The species diversity in each of the six sampling sites was compared using the Shannon-Wiener Index (H'). Hierarchical clustering and Detrended Correspondence Analysis (DCA) indicated that three main groupings of sites existed, each with a distinct community of associated species. Further analysis by Non-metric multidimensional scaling (NMDS) on the relevant distance based on species composition at the six sampling sites, together with 21 environmental variables showed that these groups were significantly associated with respective environmental variables. An updated species list of Bukit Timah dragonflies is provided for future reference, with 55 species of 43 genera in 12 families. Disturbance and threats to the odonate fauna of the Bukit Timah Nature Reserve are identified and conservation management measures are discussed.
\end{abstract}

Keywords. Community structure, ecology, Odonata, statistical analysis, tropical rain forest.

\section{Introduction}

The comprehensive biodiversity survey of the 163 ha Bukit Timah Nature Reserve (BTNR), Singapore, has been introduced by Chan \& Davison (2019). BTNR plays an important role in supporting a remarkable diversity of native plants and animals. From as early as 1860, Bukit Timah has been isolated from other forest areas by land use change. It was further separated from the Central Catchment Nature Reserve (CCNR) in 1983-86 by the construction of an expressway. Today, it is surrounded by intense urban land use such as roads and residential areas. Despite its small size, BTNR still harbours the most important patch of primary and matured secondary lowland forest in Singapore, as well as a number of endangered terrestrial and aquatic animals, including two species of endemic freshwater crabs (Khoo et al., 2019). 
Odonates (Order Odonata) are increasingly employed as biological indicators and tools for ecological modelling (Suh \& Samways, 2001; Samways, 2003; Simaika \& Samways, 2012; Bried \& Samways, 2015). They are relatively well studied taxonomically and the adults are easy to identify. They are good ecological indicators for an assessment of the aquatic environment, especially for wetland and stream quality as they occupy both aquatic and terrestrial ecosystems and are highly sensitive to environmental changes (Carvalho et al., 2013; Monteiro-Júnior et al., 2013; Oliveira-Junior et al., 2015). To date most studies of odonates in Singapore have focussed on taxonomy and species diversity (Murphy, 1997; Murphy et al., 2008; Norma-Rashid et al., 2008; Cheong et al., 2009; Tang et al., 2010; Ngiam \& Davison, 2011; Ngiam \& Leong, 2012; Ngiam \& Dow, 2013), as well as recent studies by Ngiam (2011) on dragonfly biodiversity in parks, Ngiam \& Cheong (2016) on conservation status and Cai et al. (2018) on diversity and community ecology. There are scant data on their distribution and abundance in Bukit Timah. Murphy (1997) reported odonate diversity in the nature reserves of Singapore by comprehensively reviewing the historical accounts and provided a list of species found in Singapore. He briefly discussed the distribution and habitat preferences for some species, but in his list only two species were specifically annotated as occurring in Bukit Timah. Other widely distributed species must have been found there without being mentioned specifically. Norma-Rashid et al. (2008), based on specimens deposited in the Lee Kong Chian Natural History Museum, updated the list of dragonflies in Singapore, and specified 17 species from BTNR. Tang et al. (2010) further updated the list, with 17 species occurring in BTNR.

The current study aims to establish a baseline for the abundance and diversity on selected sites and to provide the most up to date knowledge on odonates for BTNR. We also attempt to identify threats to odonates in Bukit Timah and recommend conservation measures.

\section{Methodology}

\section{Quantitative survey}

Six sites were surveyed quantitatively in different parts of the nature reserve (Sites 1 to 6, Fig. 1-3). For each survey site, eight sampling cycles were conducted from December 2014 to February 2016. Hydrological, physicochemical and habitat characteristics were recorded to analyse environmental factors that may determine the associated odonate community. Samplings of odonates were conducted between 10:30 and 13:00 hrs mostly during sunny weather conditions. For each location, sightings were recorded over 30 minutes along a $20 \mathrm{~m}$ transect of the stream and $3 \mathrm{~m}$ of riparian zone on either side of the stream bank. The transect was surveyed at a slow pace along the stream channel, counting every individual either perched or in flight. Numbers seen were collated for the eight repeats for each site and categorised as very common $(>10$ sightings), common $(5-10)$, uncommon $(<5)$ or not present. Species that could not be identified with certainty by sight were caught with an insect net and released 


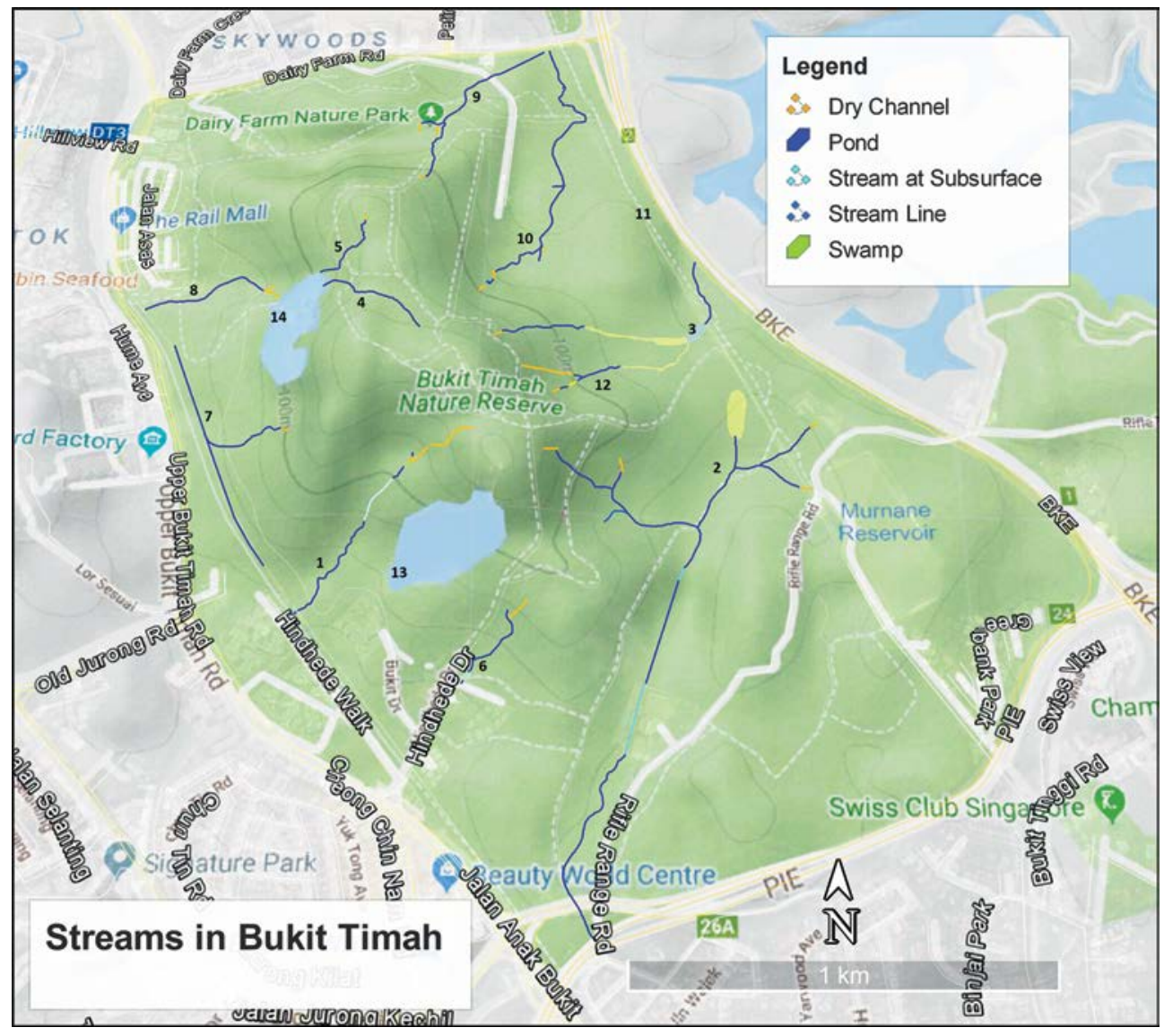

Fig. 1. Drainage map with all survey sites (Base map (C2017 Google)

after identification. Occasionally, unidentified specimens were collected for further examination.

To further investigate the habitat characteristics of the odonate fauna, which involves an aquatic component at the larval stage and a terrestrial component for adults, a number of physical and biological characteristics of the stream were quantified. Stream parameters were measured using measuring tape, a multiparameter and a flow meter. Hydraulic parameters measured included flow velocity, stream dimension (depth, width), proportion of pools, in-stream woody debris, macrophytes, leaf litter, and substrate (sand, silt). Physicochemical parameters recorded included pH, Dissolved Oxygen (DO), Oxidation-Reduction Potential (ORP), Total Dissolved Solids (TDS), Salinity, and Temperature. Riparian vegetation heterogeneity, bank form, and canopy cover were also assessed and recorded for all quantitative survey sites. The wetted stream cross-section of each site was measured multiple times to obtain the average values. The surrounding habitat types, i.e. swamp, open canopy and distance to forest edges were also recorded (see Appendix 1 for details). 


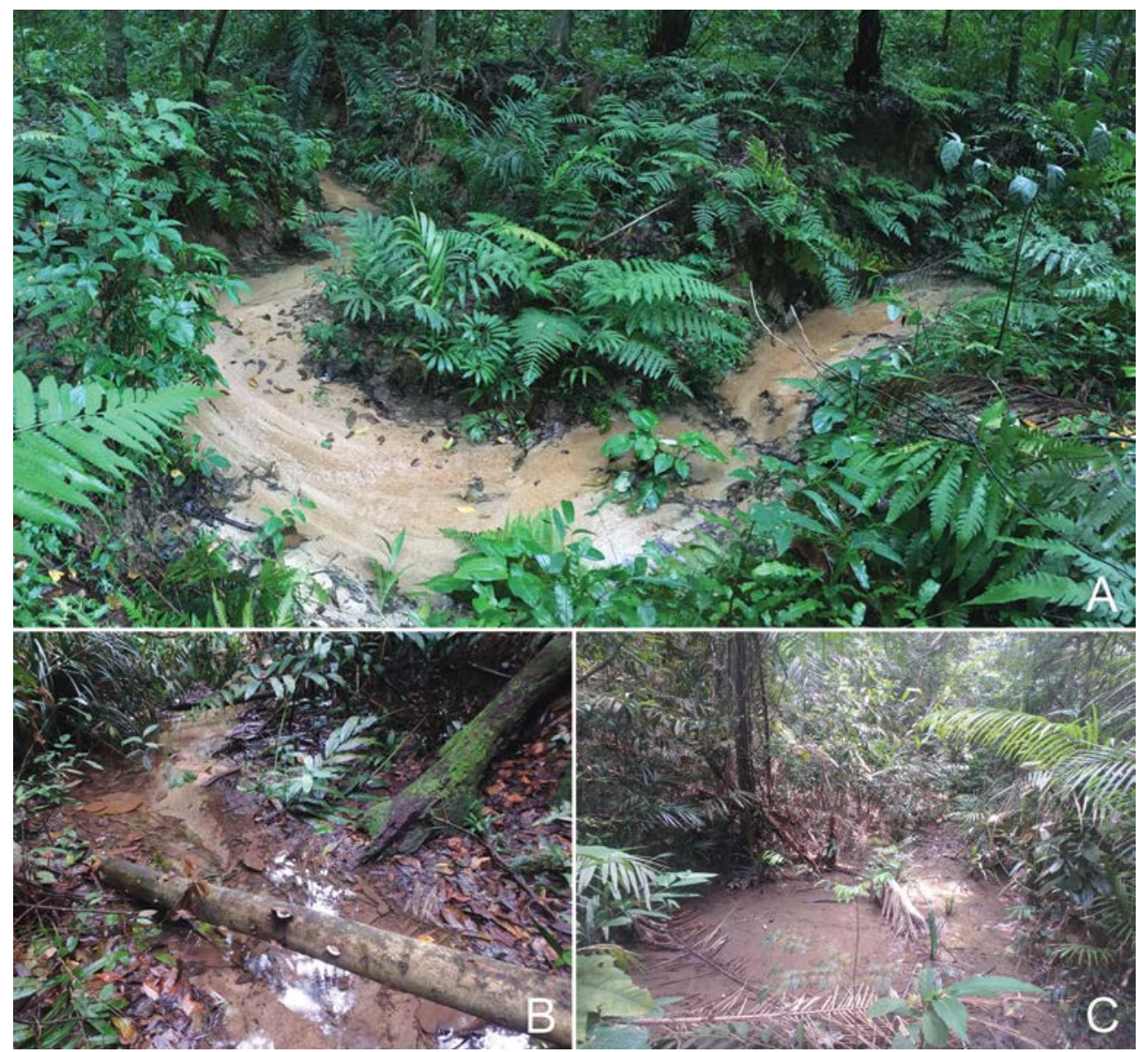

Fig. 2. Sampling sites. A. Fern Valley Stream (Site 1). B. Jungle Fall Stream (Site 4). C. Seraya Stream (Site 5). (Photos: Y. Cai)

Identifications of adults was primarily based on Tang et al. (2010) and Orr (2005). Taxonomic classification follows Schorr \& Paulson (2017). Local species updates and conservation status follow Ngiam \& Cheong (2016).

\section{Qualitative surveys}

Qualitative surveys were conducted at other water bodies in or near BTNR (Sites 7 to 14). These were predominantly sites just beyond the nature reserve boundary in Dairy Farm Nature Park, Singapore Quarry and Hindhede Park, plus one additional site (12) in BTNR at the upper section of Catchment Stream. Species seen at Sites 1-6 only outside the timed quantitative surveys were also recorded to compile a full species list. Historical records were added to provide a comprehensive updated inventory for BTNR. 

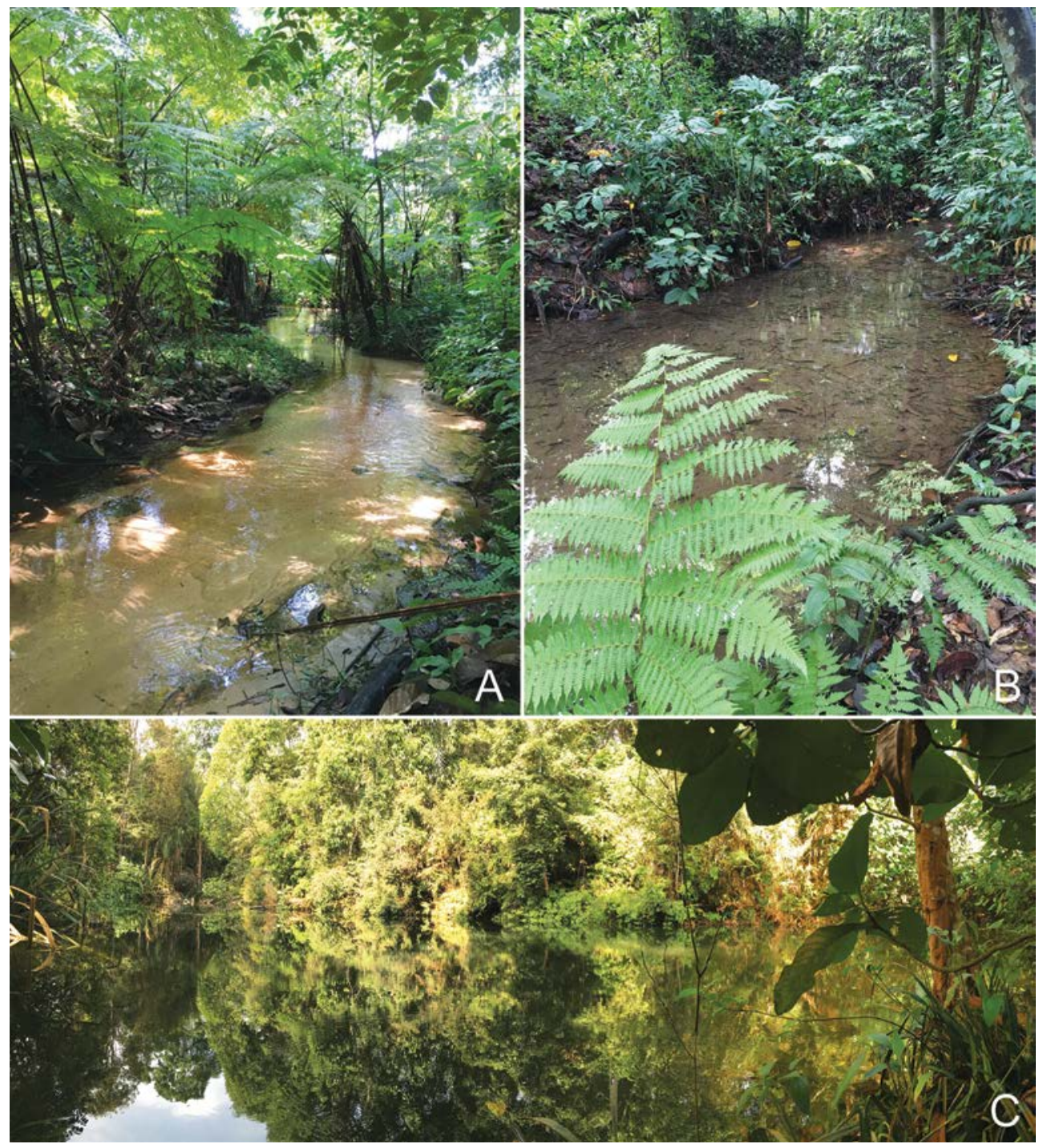

Fig. 3. Sampling sites. A. Lasia Stream (Site 2). B. Taban Pond (Site 6). C. Catchment Pond (Site 3). (Photos: Y. Cai)

\section{Data Analysis}

All data were analysed using Palaeontological Statistics (PAST 3.15) (Hammer et al., 2001; Hammer, 2017). Habitat parameter data were transformed by square root. The community count data was $\log (\mathrm{x}+1)$ transformed before analysis.

The Shannon-Wiener Index (H') was used as a measurement of species diversity. The index is calculated as $H^{\prime}=-\sum_{i=1}^{n} p_{i} \ln p_{i}$, where $\mathrm{p}_{i}$ is the proportion of individuals found of species $i$ and $n$ is the total number of species. Species Richness (R) refers to the number of species found at each site. 
Abundance of species from each survey cycle was summed from all six sites, with each species representing one sampling unit for input into a one-way ANOVA test to investigate if the dragonfly communities vary significantly across the eight sampling cycles.

Paired group (UPGMA) hierarchical clustering using Bray-Curtis similarities was carried out according to abundance and species composition of the odonate assemblage to examine if there were any natural groupings in the data. The results of the cluster analysis were overlaid onto other multivariate analysis plots to indicate graphical representation of groupings in the community.

Detrended Correspondence Analysis (DCA) was carried out to show the distribution of odonate communities across all sites. DCA is a multivariate statistical technique widely used by ecologists to find the main factors or gradients in the large, species-rich but usually sparse data matrices that typify ecological community data.

Non-metric multidimensional scaling (NMDS) was applied to analysis of the relevant distance based on species composition of the six sampling sites, together with 21 environmental variables. The environmental variables are not included in the ordination. The correlation coefficients between each environmental variable and NMDS scores are presented as vectors from the origin. The length of the vectors is arbitrarily scaled to make a readable biplot, so only their directions and relative lengths should be considered. Line linking group/sites show the minimal spanning tree which is based on the selected similarity or distance index in the original space. The results were used to suggest the most influential environmental variables that shaped the current species distribution pattern in BTNR.

\section{Results}

\section{Abundance and diversity of odonates in BTNR}

A total of 829 odonate specimens were sampled quantitatively, comprising 36 species of 28 genera in 11 families. The suborder Zygoptera (damselflies) was represented by 447 individuals, distributed in seven families (Argiolestidae, Calopterygidae Coenagrionidae, Devadattidae, Euphaeidae, Platycnemididae, and Platystictidae), 10 genera and 12 species. The suborder Anisoptera (dragonflies) contributed 382 individuals, distributed in four families (Aeshnidae, Gomphidae, Libellulidae and Macromiidae), 18 genera and 24 species.

\subsection{Abundance and distribution of Odonates within Bukit Timah Nature Reserve}

There were 36 species recorded in the quantitative surveys at six sites, another four species recorded at the same sites outside the sampling periods, and 29 species that were recorded during qualitative surveys at the remaining sites (Table 1), resulting in the total of 43 species seen. Five species were found only at Catchment Pond, two only at the pipeline stream and two only at Singapore Quarry. 
Table 1. Number of species of Odonata recorded at each of 14 study locations in and immediately around Bukit Timah Nature Reserve, Singapore.

\begin{tabular}{|c|c|c|c|c|c|}
\hline $\begin{array}{l}\text { Site } \\
\text { no. }\end{array}$ & Name & $\begin{array}{l}\text { Quantitative } \\
\text { sampling }\end{array}$ & $\begin{array}{l}\text { Qualitative } \\
\text { sampling }\end{array}$ & $\begin{array}{l}\text { Total species } \\
\text { recorded }\end{array}$ & $\begin{array}{l}\text { Only found } \\
\text { at one site }\end{array}$ \\
\hline 1 & Fern Valley & 8 & & 8 & \\
\hline 2 & Lasia Stream & 14 & & 14 & \\
\hline 3 & Catchment Pond & 28 & 3 & 31 & 5 \\
\hline 4 & Jungle Fall & 4 & & 4 & \\
\hline 5 & Seraya Stream & 5 & & 5 & \\
\hline 6 & Taban Stream & 5 & 1 & 6 & \\
\hline 7 & Rail Corridor & & 8 & 8 & \\
\hline 8 & Asas Stream & & 4 & 4 & \\
\hline 9 & Dairy Farm & & 6 & 6 & \\
\hline 10 & Wallace Stream & & 14 & 14 & \\
\hline 11 & Pipeline & & 11 & 11 & 2 \\
\hline 12 & Catchment Stream & & 5 & 5 & \\
\hline 13 & Hindhede Quarry & & 7 & 7 & \\
\hline \multirow[t]{2}{*}{14} & Singapore Quarry & & 10 & 10 & 2 \\
\hline & TOTAL & 36 & 33 & 43 & 9 \\
\hline
\end{tabular}

Prodasineura notostigma (Fig. 4A) was the most abundant Zygopteran species ( $\mathrm{n}=158$ specimens), found at all six sites, followed by Ceriagrion cerinorubellum $(\mathrm{n}=85)$ occurring at three sites. Orthetrum chrysis was the most abundant Anisopteran species $(\mathrm{n}=76)$, found at all six sites, followed by Tyriobapta torrida $(\mathrm{n}=65)$, found at two sites. Podolestes orientalis (Fig. 4D), Vestalis amethystine (Fig. 4E), Amphicnemis gracilis (Fig. 4C), Ceriagrion cerinorubellum, Devadatta argyoides (Fig. 4B) and Epophthalmia vittigera were found at three of the six sites. 20 species were only found from one survey site. Relative species richness per survey site varied from two (Site 5) to 13 (Site 3), mean abundance of individuals recorded per survey site varied from three (Site 5) to 54 (Site 3). The species found in each of the collection sites are detailed in Table 2. 


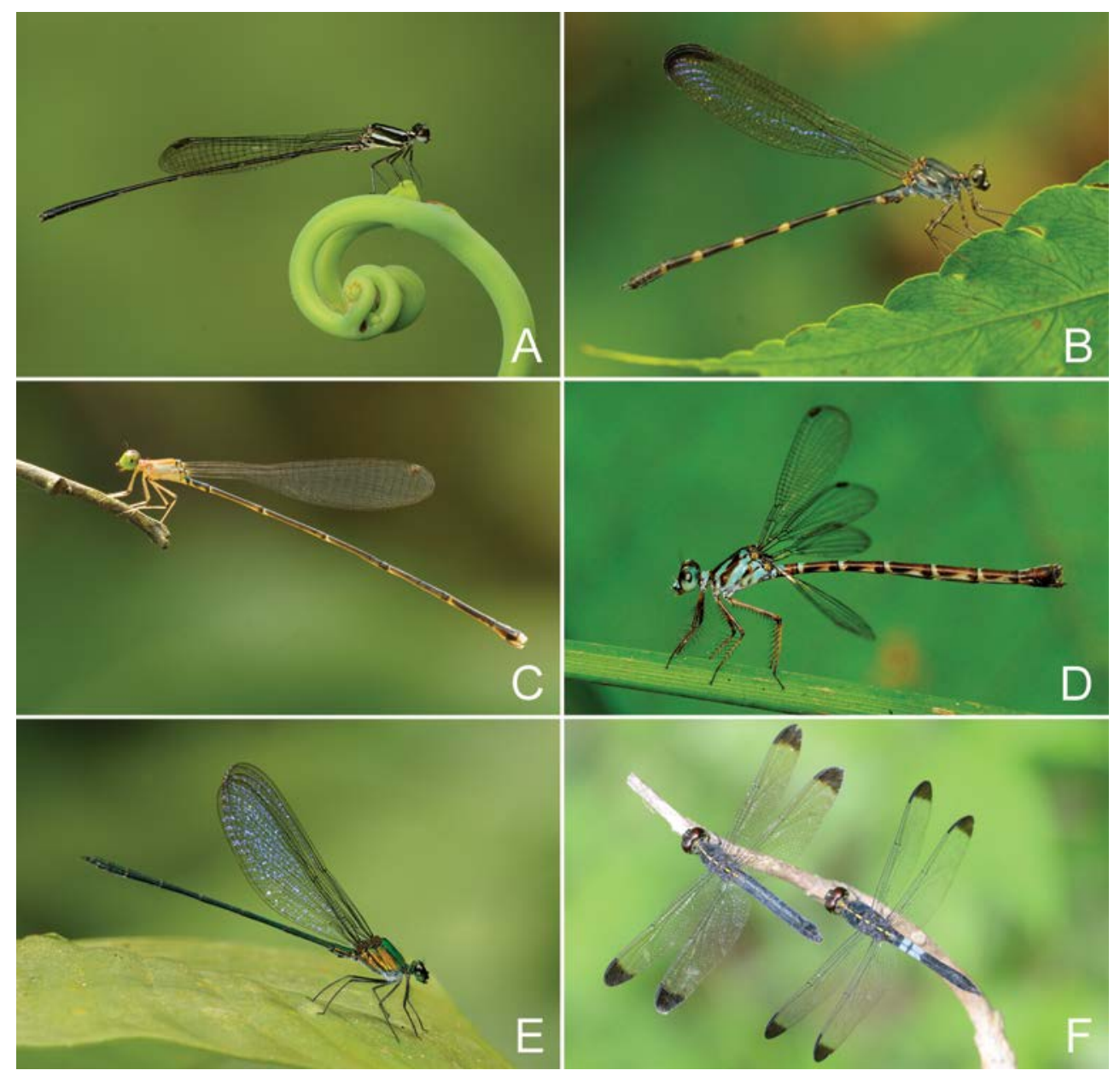

Fig. 4. A. Prodasineura notostigma. B. Devadatta argyoides. C. Amphicnemis gracilis. D. Podolestes orientalis. E. Vestalis amethystine. F. Cratilla metallica. (Photos: Y. Cai)

\subsection{Spatial variation in odonate abundance, species richness and diversity}

The species richness and abundance of odonates in each survey site were collated from the eight sampling cycles and the results are presented in Fig. 5. Species richness was further analysed by the average value of the eight sampling cycles (Fig. 6). Among the six sites, Site 3 (Catchment Pond) shows distinctly much higher abundance and species richness than the rest of sites. Site 1 (Fern Valley) and Site 2 (Lasia) are slightly higher than Site 4 (Jungle Fall) and Site 6 (Taban Pond). Site 5 (Seraya) is the lowest for both abundance and species richness. Mean species richness ranges from 1.88 to 12.75 species/site with the highest mean species richness at Site 3 and the lowest at Site 5. 


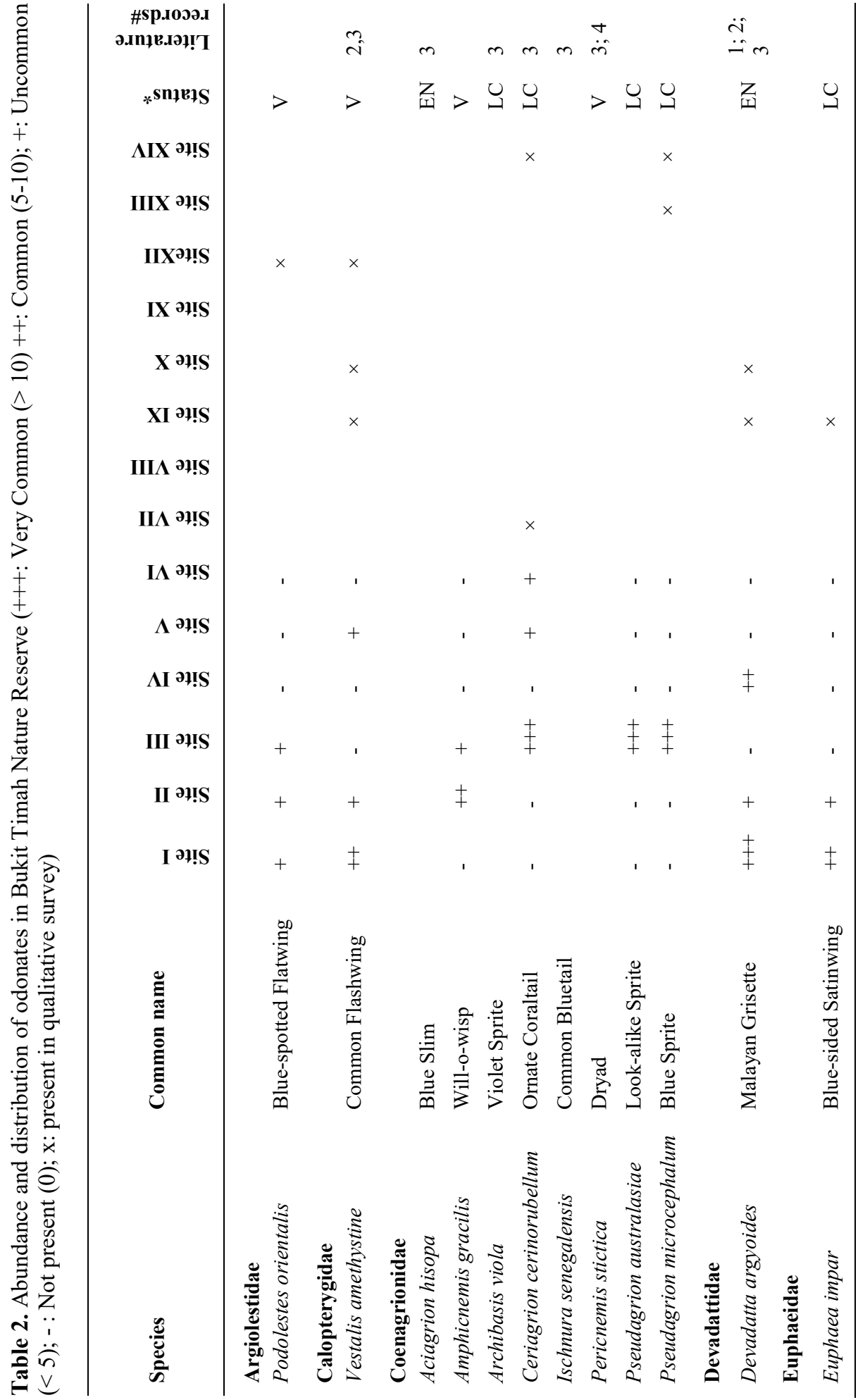




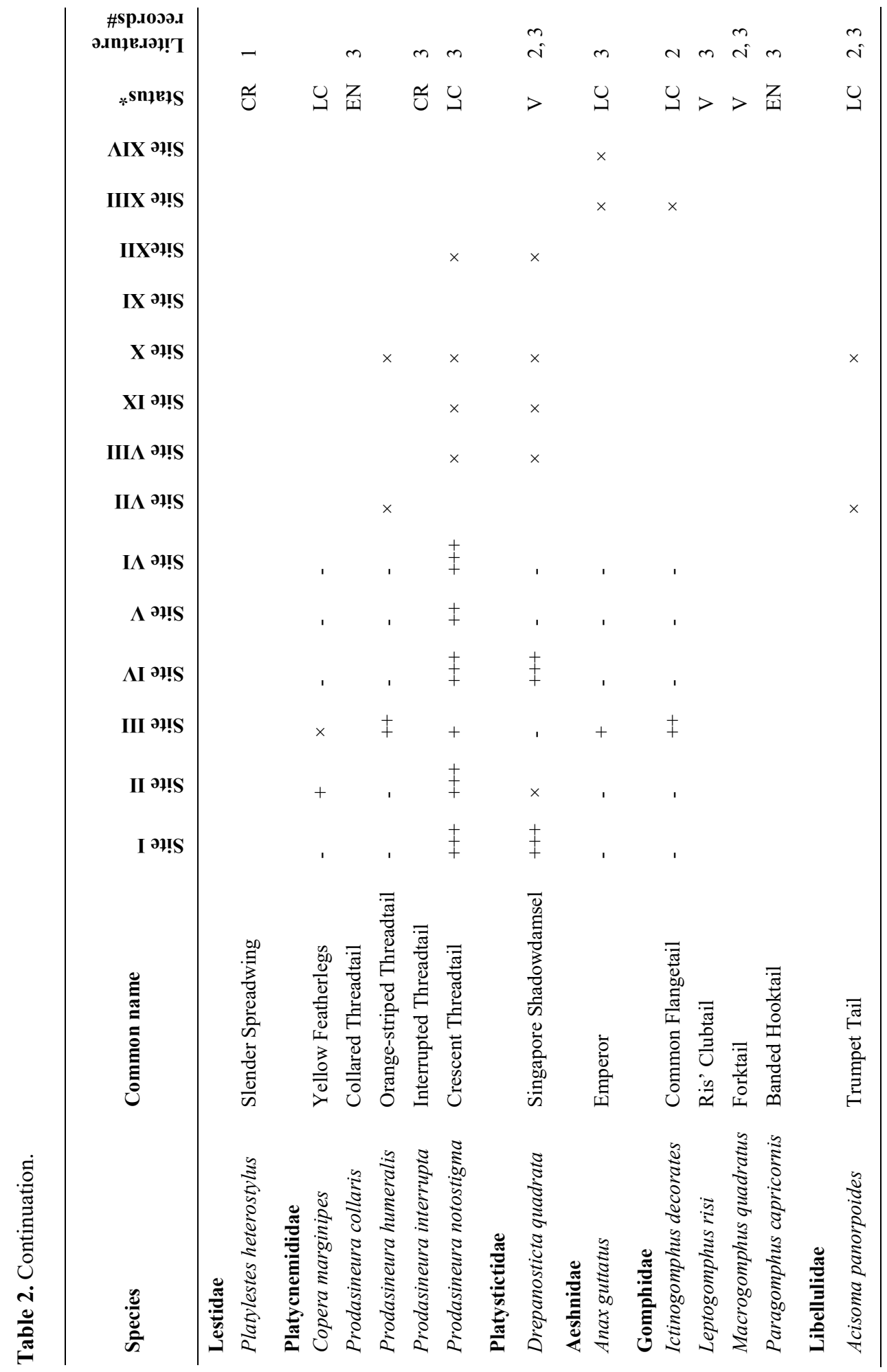




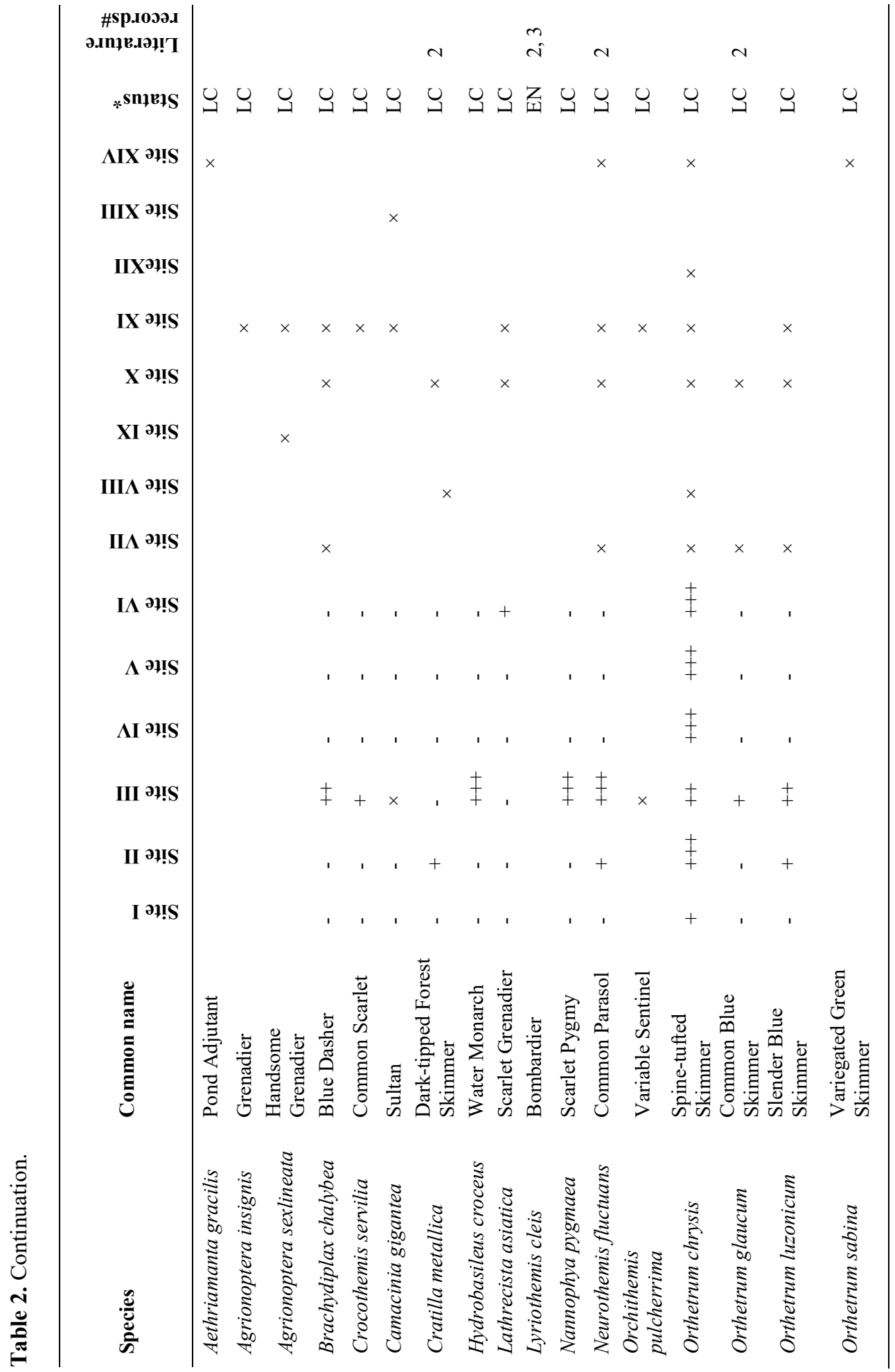




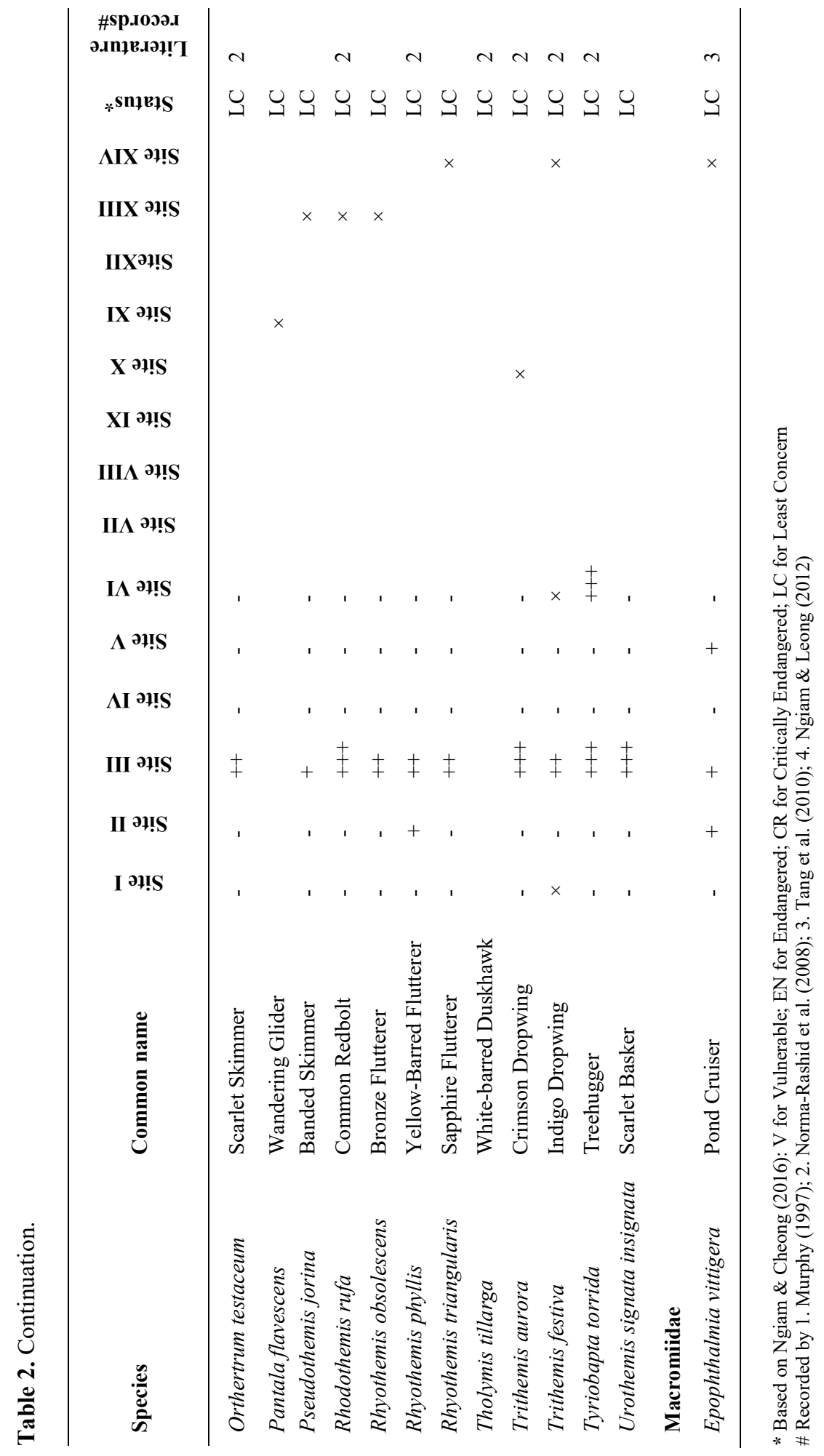




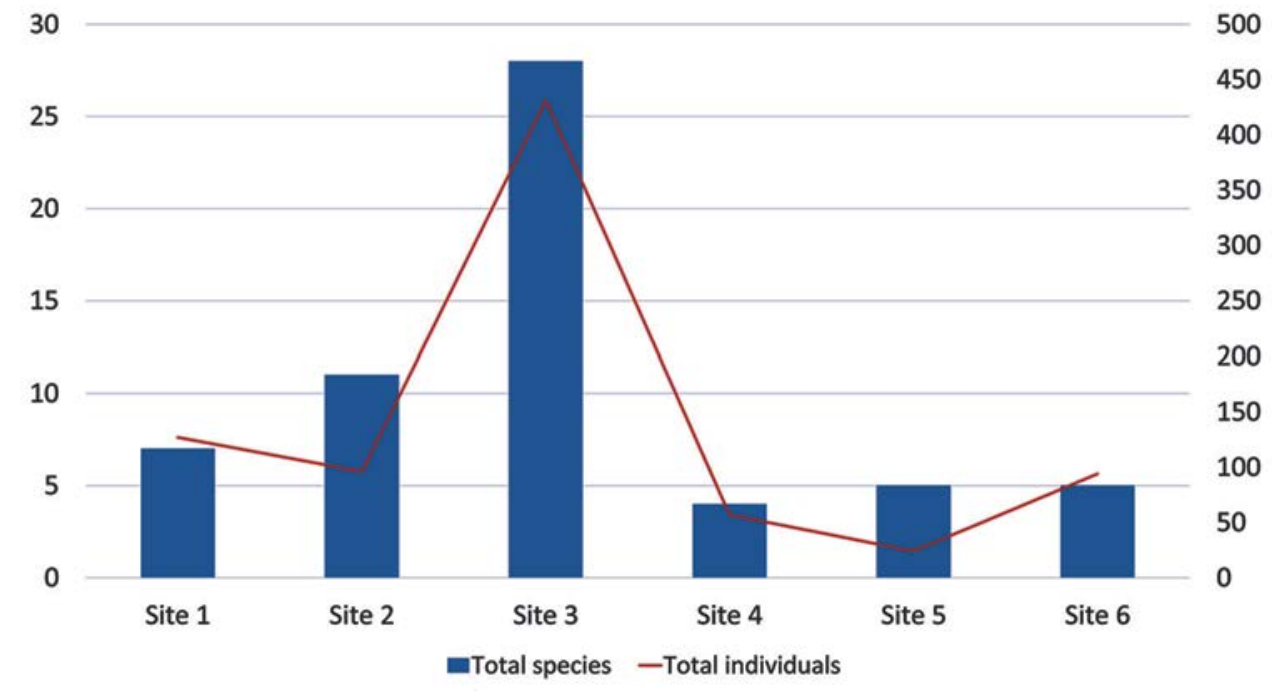

Fig. 5. Species richness and abundance graph of odonates at various survey sites

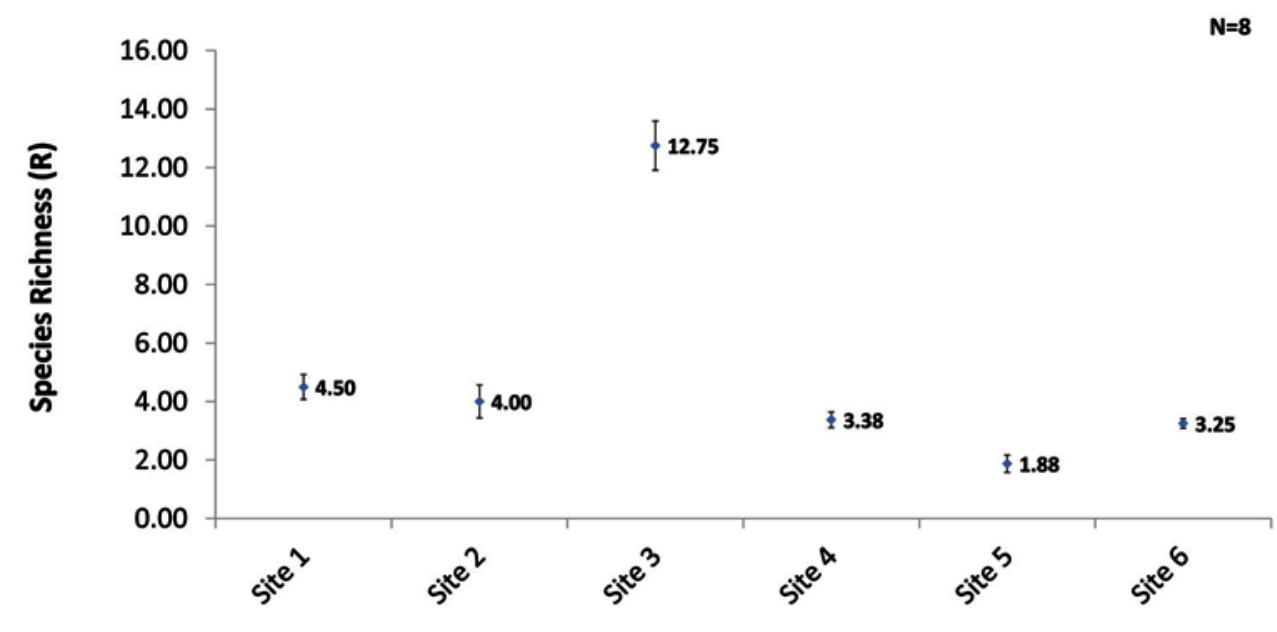

Survey sites

Fig. 6. Mean species richness graph of odonates at various survey sites $(\mathrm{N}=8$, Error $\mathrm{Bar}= \pm 1 \mathrm{SE})$

The mean species diversity at each survey site was plotted using ShannonWiener index (H') (Fig. 7). Site 3 (Catchment Pond), with a H' value of 0.99, had the greatest species diversity, while Site 5 (Seraya), with a H'value of 0.22 , had the lowest species diversity. 


\subsection{Temporal variation in odonate abundance and species richness}

The abundance of each species from each survey cycle was summed for all six sites. Each species then represented one sampling for input into a one-way ANOVA test to investigate if the dragonfly community varied over the eight sampling cycles. The result (Table 3) shows that the difference is not significant.

\section{Distribution pattern and habitat characteristics}

Hierarchical clustering (Fig. 8) and DCA (Fig. 9) indicated that three groups of sites could be recognised, each with a certain number of associated species. Based on oneway PERMANOVA test (Similarity index of Bray-Curtis, Permutation N=9999) all groups differ significantly from each other $(p=0.0166)$. Further analysis by NMDS (Fig. 10) with 21 environmental variables showed that these groups were significantly associated with several environmental variables. The first group consists of Site 1, Site 2 and Site 4 . These are relatively undisturbed hill streams. The species represented in this group are mainly Prodasinura notostigma, Devadatta argyoides, Euphaea impar, Drepanosticta quadrata and Vestalis amethystina. All of these are typical forest damselfly species. The environmental variables that best describe this group are stream with sandy substrate; denser canopy cover; fast flowing water with high DO and ORP. The second group is formed by Site 5 and Site 6. There is no particular species associated with this group, except that the common stream dragonfly Orthetrum chrysis is more abundant. All species found at these two sites also occur in other groups of sites. The environmental variables that best describe this group are stream water with high value of TDS, and salinity, less DO, as well as stream with a smoother bank.

The species found at Site 3 are sufficiently different from all other sites to form another group. Many of these species are typical of open or broken canopy, with 16 species of dragonflies (Anax guttatus, Ictinogomphus decoratus, Brachydiplax chalybea, Crocothemis servilia, Hydrobasileus croceus, Nannophya pygmaea, Orthetrum glaucum, Orthetrum luzonicum, Orthertrum testaceum, Pseudothemis jorina, Rhodothemis rufa, Rhyothemis obsolescens, Rhythemis triangularis, Trithemis aurora, Trithemis festiva, Urothemis signata insignata) and three species of damselflies (Prodasineura humeralis, Pseudagrion microcephalum, Pseudagrion australasiae) only recorded from this site during quantitative sampling. The environmental variables that best describe this site are the greater depth of water, higher $\mathrm{pH}$, location at forest margins, riparian with higher heterogeneity, and water body with high amount of in-stream macrophytes and woody debris. Although streams in group 1 and group 2 are closer in terms of species composition and abundance as indicated by the cluster analysis, the NMDS results show that group 2 shares a number of environmental parameters with group 3, e.g. existence of swamp habitats in the vicinity, presence of distinct pool habitats in water channel, stream substrate with high amount of silt and leaf litter, greater channel width, and water with higher temperature. 


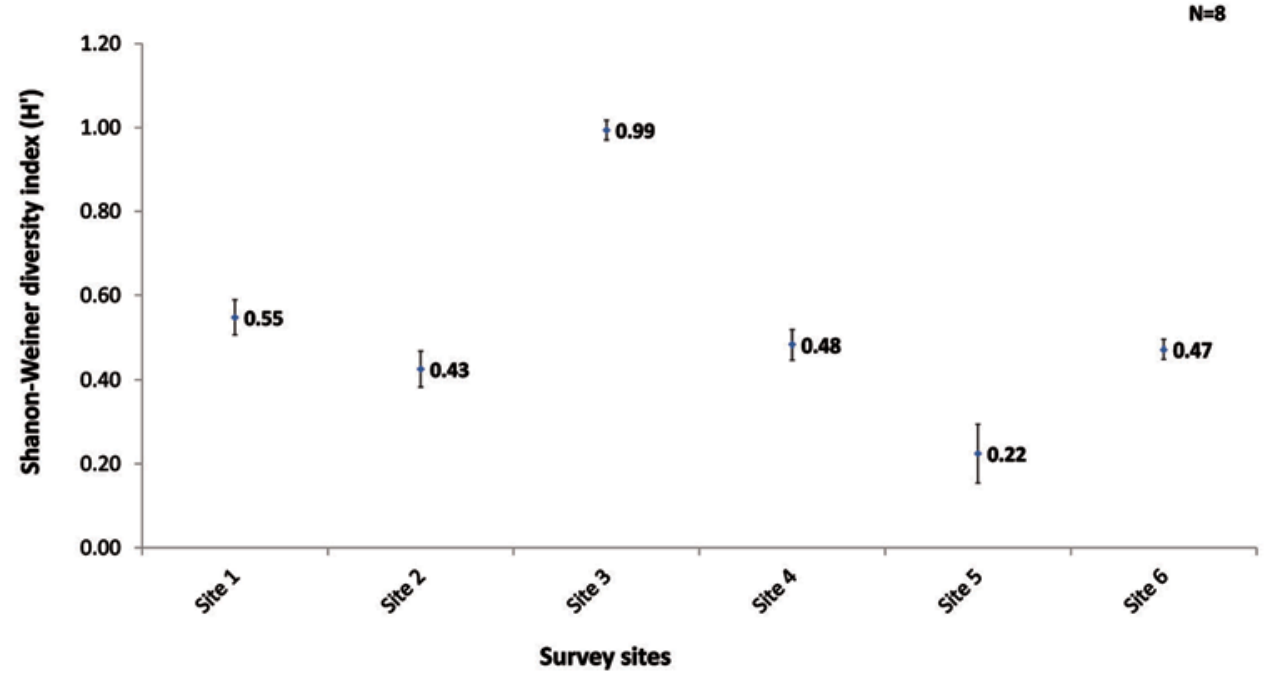

Fig. 7. Mean species biodiversity index graph of odonates at various survey sites $(\mathrm{N}=8$, Error $\mathrm{Bar}= \pm 1 \mathrm{SE}$ )

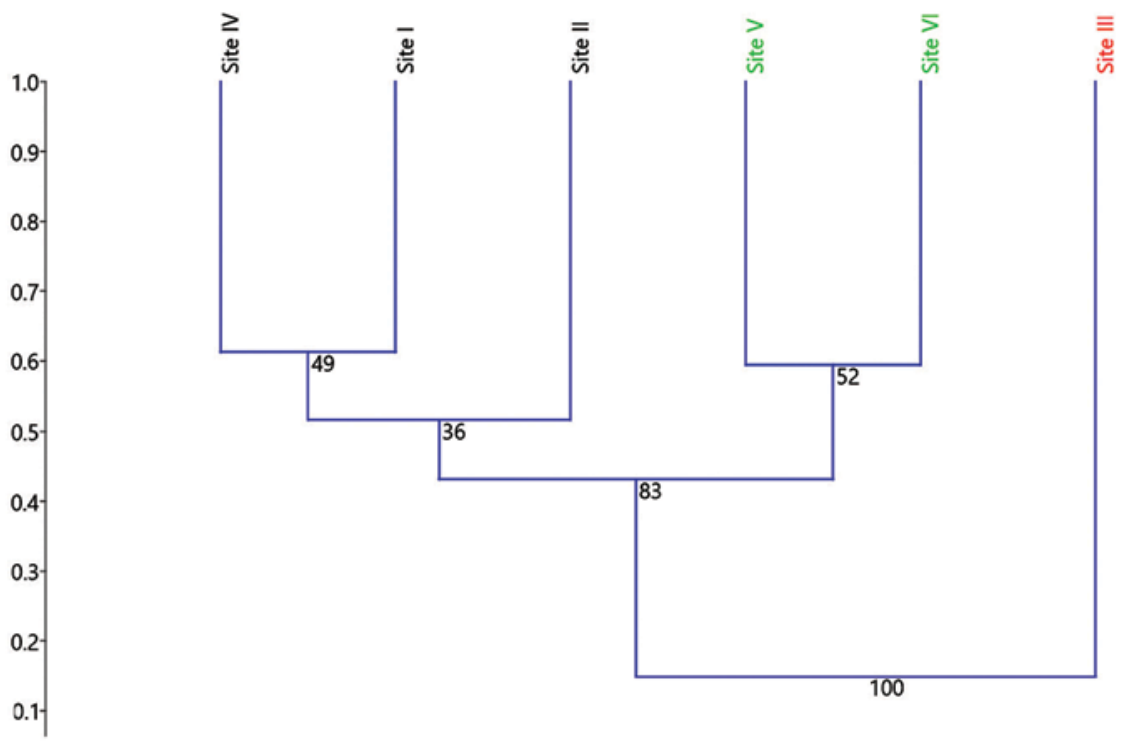

Fig. 8. Hierarchical clustering of sites according to odonate assemblage. Three clusters were recognized, colour coded in black, green and red. 
Table 3. One-way ANOVA result

\begin{tabular}{lllllll}
\hline & $\begin{array}{l}\text { Sum of } \\
\text { squares }\end{array}$ & $\begin{array}{l}\text { Degrees of } \\
\text { freedom }\end{array}$ & Mean square & Fs & p & $\begin{array}{l}\text { Variance } \\
\text { component (\%) }\end{array}$ \\
\hline Among groups & 79.761 & 7 & 11.394 & 0.46 & 0.863 & -1.61 \\
Within groups & 6538.618 & 264 & 24.767 & & 101.61 \\
\hline Total & 6618.379 & 271 & & & & \\
\hline
\end{tabular}

\section{Discussion}

Biodiversity baselines for odonates of BTNR

From the pooled quantitative and qualitative surveys, we recorded 43 species from 33 genera in 11 families. Relative species richness per survey site varied from one to 16 , and mean abundance of odonate individuals recorded per survey site varied from one to 83. An updated species list of Bukit Timah dragonflies is provided for future reference, with 55 species from 43 genera in 12 families, representing about $40 \%$ of all odonates ever recorded in Singapore. The mean species richness $(\mathrm{R})$ of the sites ranges from 1.88 to 12.75 . Hence there is a greater difference between sites as compared to Nee Soon freshwater swamp forest (NSSF) (Cai et al., 2018) which has species richness ranging from 3.5 to 9.25 . The mean biodiversity index (H') of various sites also has much higher variation, ranging from 0.22 to 0.99 in BTNR as compared to 0.46 to 0.88 reported from NSSF (Cai et al., 2018).

Compared to historical records, the changes in occurrence and distribution of the genus Prodasineura in BTNR is most remarkable. Murphy (1997: 343, figure 4) plotted records of three Prodasineura species, commenting that "none of these have been found outside the Central Catchment Nature Reserves (CCNR) in Singapore and the genus is not known from Bukit Timah." Based on the current study, Prodasinura notostigma is now the most abundant and widely distributed species in BTNR, while P. humeralis is found at the outskirts of the nature reserve. Tang et al. (2010) indicated the occurrence of Prodasinura collaris and $P$. interrupta in BTNR, with no specific locations mentioned. Despite comprehensive searching throughout the stream and pond habitats in this study, we were unable to find the latter two species. The occurrence of Prodasinura humeralis could be due to dispersal from a recent unintended introduction event, as suggested by Cai et al. (2018). However, the current dominance of a species that was previously unrecorded from BTNR is unexpected and warrants further investigation.

\section{Community structures and distribution patterns}

From the results of the current study, the odonates of BTNR can be grouped into three community assemblages, i.e. a community associated with pristine or less 


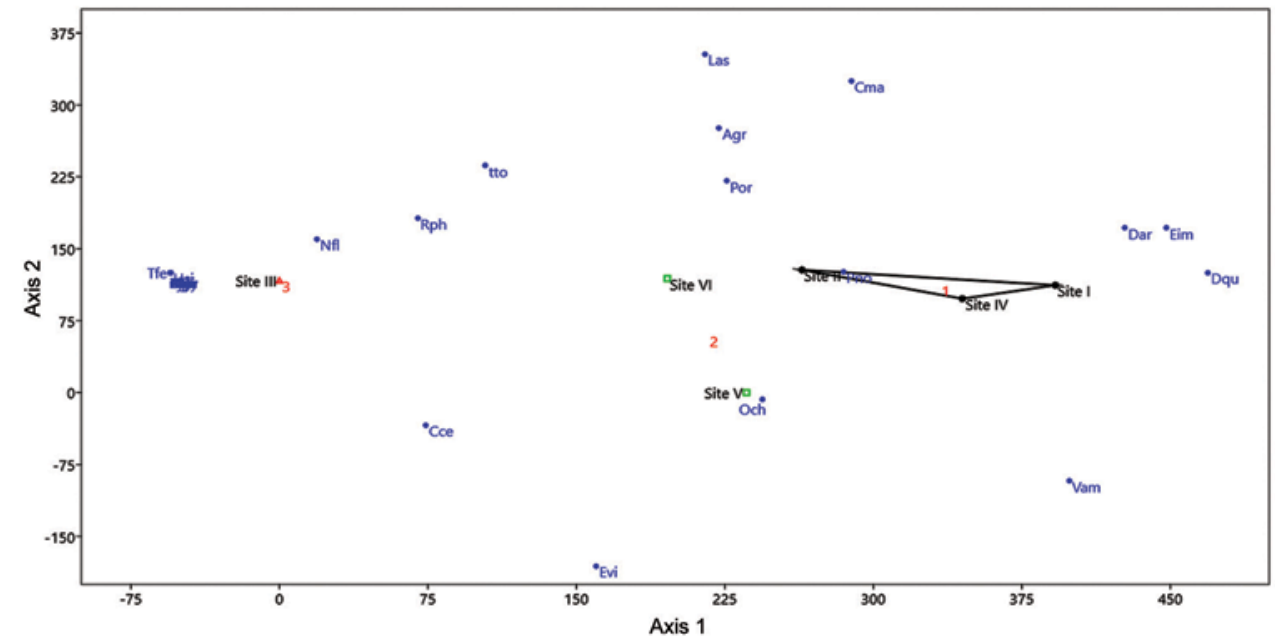

Fig 9. Detrended Correspondence Analysis (DCA) results showing the distribution of odonate communities across all sites. Sites are grouped into group 1 in black, group 2 in green and group 3 in red corresponding to results of cluster analysis. (Please refer to Appendix 2 for abbreviation for the species)

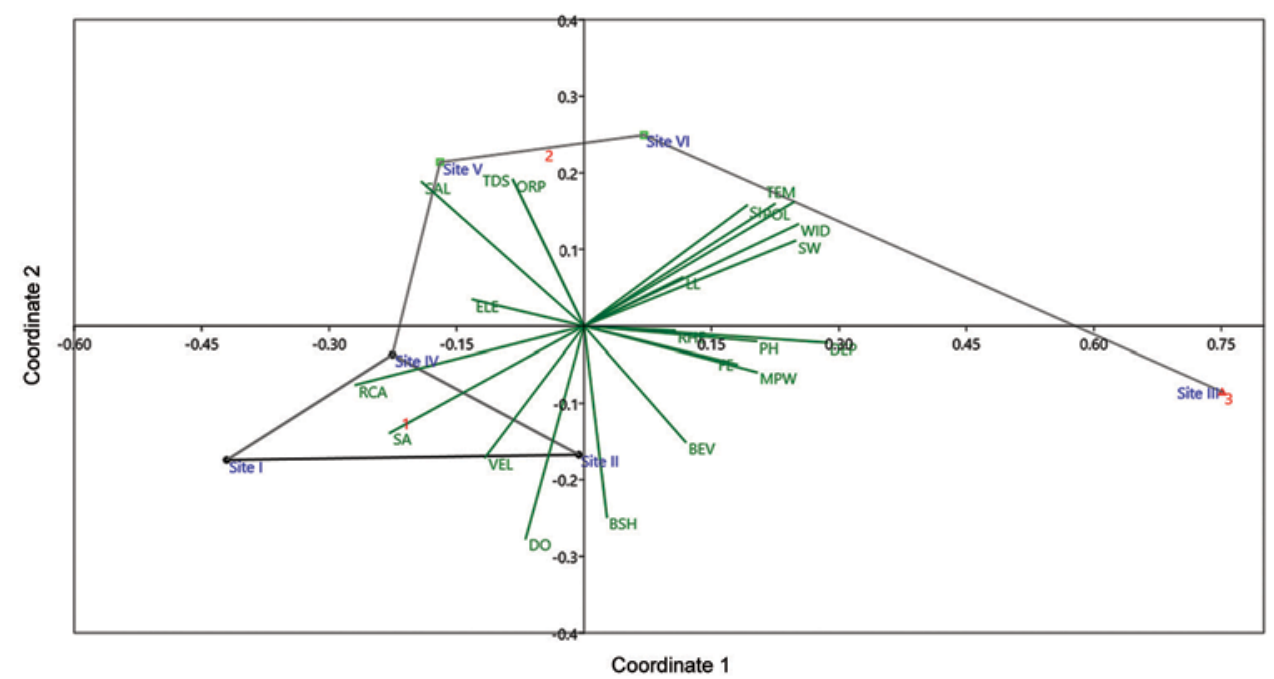

Fig. 10. Non-Parametric Multidimensional Scaling (NMDS) results showing the groups of site position and the relevant influential environmental variables. Circular (black): sites in group 1; Square (green): sites in group 2; Triangle (red): sites in group 3. Line linking group/sites indicated the minimal spanning tree which is based on the selected similarity or distance index in the original space. (Please refer to Appendix 1 for abbreviation of the parameters) 
disturbed hill streams, a community associated with median level disturbance of hill streams, and a community associated with highly modified open water habitats. Each of these community assemblages is associated with a distinctive suite of hydrogeomorphological, physicochemical characteristics and riparian vegetation in accordance with the level of anthropogenic disturbance. Site 3 is located at the lower reach of a hill stream which was impounded to form a large pond when Bukit Timah Expressway (BKE) was built in the 1980s. The condition of the pond has become naturalised over the years, and the habitat characteristics are totally different compared to the original forest stream habitats. The odonate species found there are mostly associated with open water and open canopy habitats. Despite their upper reaches displaying a typical hill stream character, both Site 5 and Site 6 are more associated with a distinct water body caused by the construction of hiking or cycling trails. The sluggish streams provide micro-habitats that are distinguished from others by e.g. silted substrate, lower canopy cover, slow flowing water and higher water temperature. Sites 1, 2, \& 4 retain most of their forest stream characteristics, and have less anthropogenic influence. Thus, they support a large portion of the endangered and uncommon damselfly species. Despite the close proximity of Site 2 and Site 6 at lower elevation, and Site 4 and site 5 at relatively higher elevation, our results show that their respective odonate fauna are distinctly different from each other.

Community assembly theory is founded on the premise that the relative importance of local environmental processes and dispersal shapes the compositional structure of metacommunities. Four general models describe interesting combinations of these factors and are frequently used to interpret observed communities: neutral model, patch dynamics, mass-effect, and species sorting (cf. De Marco Jr et al., 2015). The species sorting model predicts that assemblages are dominated by the environmental filtering of species that are readily able to disperse to suitable habitats (De Marco Jr et al., 2015). The species sorting model could explain the current species composition and community structure of the odonate fauna found in BTNR.

\section{Conservation Management and Future Prospects}

Land use change in the surrounding area, variations of the hydro-geomorphological conditions of streams in Bukit Timah, as well as changes in riparian forest structure over the last 150 years have shaped the current community structure of the odonate fauna which must now be significantly different from that in Wallace's time when he made the first collection of odonate specimens in Singapore in 1854 (Murphy, 1997). These continue to be the biggest threats to odonate biodiversity in BTNR.

Of the 55 species of odonates so far known from BTNR, 14 are of conservation concern, including two critically endangered, five endangered, and seven vulnerable species (Table 2). Unfortunately, despite comprehensive sampling throughout all possible habitats in this study, more than half of those listed historically were not recorded during the present survey, including the two critically endangered 
(Platylestes heterostylus, Prodasinura interrupta), four endangered (Aciagrion hisopa, Prodasinura collaris, Paragomphus capricornis, Lyriothemis cleis) and two vulnerable species (Leptogomphus risi, Macrogomphus quadratus). Some of these species, e.g. P. heterostylus, might have been extirpated from BTNR. Tang et al. (2010: 48) documented that "Platylestes heterostylus is very rare in Singapore. It was found at Bukit Timah in 1960-1970's and was last recorded at the west end of MacRitchie Reservoir on 29 August 1980. It inhabits open and forested swamp...." We posit that both a narrow ecological niche requirement of these species and changes in abiotic and biotic environmental conditions in BTNR for the last few decades could be the reasons for possible species extirpation.

Conservation actions to minimize the disturbance and reduce the threats will require in-depth studies of the microhabitat-dependent distribution of odonates. The main focus of the current study was on adult odonates, as larvae were only collected as secondary sampling during the survey of aquatic fauna (fish, crustaceans, aquatic insects) that took place simultaneously (Li et al., 2019; Khoo et al., 2019; Lee, 2015). Patten et al. (2015) commented that surveys of adult dragonflies can paint a misleadingly broad picture of a species' ecological niche. The evidence of breeding, especially the presence of tenerals or exuviae, should be used to outline ecological requirements. Hence, future study of odonates in BTNR should dedicate more effort towards the collection and identification of larvae as well as their associated microhabitats. Stream water acidification has been identified as one of the possible causes responsible for the extirpation of the Singapore freshwater crab (Johora singaporensis) from its type locality in BTNR (Ng et al., 2014). Has a similar scenario happened or is it now happening to some of the odonate species whose larvae cannot survive high acidity? Besides water quality, other hydrogeomorphological changes to the streams in BTNR may also have important impacts on the sustainability of the odonate fauna. Mitigation measures based on multidisciplinary study of stream hydrology and ecology of BTNR to minimize the disturbance and threats should be conducted to guide the conservation effort. Longterm monitoring is needed to build on current knowledge and capture long term trends. Adoption of standardised survey techniques and sampling protocols such as those applied in the current study will enable us to better understand the long-term changes and their drivers. Other management options include stream rehabilitation and enhancement, the reintroduction of native species to their original habitats, and development of a dragonfly awareness trail for outreach and education. A guided tour along a trail linking sites 3, 2, 6, 7 and 14 would provide easy access to various habitats and diverse odonate fauna. The suggested awareness trail is short and would have low impact on the BTNR core conservation area.

ACKNOWLEDGEMENTS. We would like to thank Lena Chan, Geoffrey Davison, Adrian Loo, Lim Liang Jim, Thereis Choo, Cheryl Chia for their support, Chong Kwek Yan for discussion on biostatistics, Lim Weihao, Li Tianjiao, Loh Yu Xuan, Audrey Lee, Nigel Tiong and colleagues from the National Biodiversity Centre for their help with field surveys. 


\section{References}

Bried, J.T. \& Samways, M.J. (2015). A review of odonatology in freshwater applied ecology and conservation science. Freshw. Sci. 34: 1023-1031.

Cai, Y., Ng, C.Y. \& Ngiam, R.W.J. (2018). Diversity, distribution and habitat characteristics of dragonflies in Nee Soon freshwater swamp forest, Singapore. Gard. Bull. Singapore 70 (Suppl. 1): 123-153.

Carvalho, F.G., Pinto, N.S., Oliveira Jr., J.M.B. \& Juen, L. (2013). Effects of marginal vegetation removal on Odonata communities. Acta Limnol. Bras. 25(1): 10-18.

Chan, L. \& Davison, G.W.H. (2019). Introduction to the Comprehensive Biodiversity Survey of Bukit Timah Nature Reserve, Singapore, 2014-2018. Gard. Bull. Singapore 71 (Suppl. 1): 3-17.

Cheong, L.F., Tang, H.B. \& Ngiam, R.W.J. (2009). New records for Singapore dragonflies. Agrion 13(1): 8-13.

De Marco Jr., P., Batista, J.D. \& Cabette, H.S.R. (2015). Community assembly of adult odonates in tropical streams: an ecophysiological hypothesis. PLOS ONE 10(4): $\mathrm{e} 0123023$.

Hammer, Ø. (2017). PAST, Paleontological statistics, version 3.15, reference manual. Norway: Natural History Museum, University of Oslo.

Hammer, Ø., Harper, D.A.T., \& Ryan, P.D. (2001). PAST: Paleontological Statistics Software Package for Education and Data Analysis. Palaeontol. Electron. 4(1): 1-9.

Khoo, M.D.Y., Tiong, N.J.L., Li, T., Lim, W., Ng, D.J.J., Nyanasengeran, M., Yeo, D.C.J. \& Cai, Y. (2019). The freshwater decapod crustaceans of Bukit Timah Nature Reserve, Singapore. Gard. Bull. Singapore 71 (Suppl. 1): 575-581.

Lee, A.Y.X. (2015). Biodiversity Assessment of Aquatic insects in Bukit Timah Nature Reserve streams. B.Sc. thesis, Nanyang Technological University, Singapore.

Li, T., Loh, Y.X., Lim, W., Nyanasengeran, M., Low, B.W., Tan, H.H., Yeo, D.C.J. \& Cai, Y. (2019). The fish fauna of Bukit Timah Nature Reserve, Singapore. Gard. Bull. Singapore 71 (Suppl. 1): 557-573.

Monteiro-Júnior, C.S., Couceiro, S.R.M., Hamada, N. \& Juen, L. (2013). Effect of vegetation removal for road building on richness and composition of Odonata communities in Amazonia, Brazil. Int. J. Odonatol. 16(2): 135-144.

Murphy, D.H. (1997). Odonata biodiversity in the Nature Reserves of Singapore. Proceedings of the Nature Reserves Survey Seminar. Gard. Bull. Singapore 49: 333-352.

Murphy, D.H., Cheong, L.F., Wang, L.K. \& Ang, S. (2008). Springtails, peripatus and insects. In: Davison, G.W.H., Ng, P.K.L. \& Ho, H.C. (eds) The Singapore Red Data Book: Threatened Plants and Animals of Singapore, $2^{\text {nd }}$ ed., pp. 62-104. Singapore: Nature Society (Singapore).

Ngiam, R.W.J. (2011). Dragonflies of our parks and gardens. Singapore: National Parks Board.

Ngiam, R.W.J. \& Cheong, L.F. (2016). The dragonflies of Singapore: An updated checklist and revision of the national conservation statuses. Nat. Singapore 9: 149-163.

Ngiam, R.W.J. \& Davison, G.W.H. (2011). A checklist of dragonflies in Singapore parks (Odonata: Anisoptera, Zygoptera). Nat. Singapore 4: 349-353.

Ngiam, R.W.J. \& Dow, R.A. (2013). The larva of Leptogomphus risi Laidlaw from Singapore with a comparison to Leptogomphus williamsoni Laidlaw from Sarawak and congeners (Odonata: Anisoptera: Gomphidae). Nat. Singapore 6: 307-312. 
Ngiam, R.W.J. \& Leong, Z.M. (2012). Larva of the phytotelm-breeding damselfly, Pericnemis stictica Selys from forests in Singapore (Odonata: Zygoptera: Coenagrionidae). Nat. Singapore 5: 103-115.

Ng, J.J.D., Yeo, D.C.J., Sivasothi, N. \& Ng, P.K.L. (2014). Conservation challenges and action for the Critically Endangered Singapore freshwater crab Johora singaporensis. Oryx 49: 345-351.

Norma-Rashid, Y., Cheong, L.F., Lua, H.K. \& Murphy, D.H. (2008). The dragonflies (Odonata) of Singapore: Current status records and collections of the Raffles Museum of Biodiversity Research. Singapore: Raffles Museum of Biodiversity Research, National University of Singapore.

Oliveira-Junior, J.M.B., Shimano, Y., Gardner, T.A., Hughes, R.M., De Marco Jr., P. \& Juen, L. (2015). Neotropical dragonflies (Insecta: Odonata) as indicators of ecological condition of small streams in the eastern Amazon. Austral Ecol. 40: 733-744.

Orr, A.G. (2005). Dragonflies of Peninsular Malaysia and Singapore. Kota Kinabalu, Malaysia: Natural History Publications (Borneo).

Patten, B.M., Bried, J.T. \& Smith-Patten, B.D. (2015). Survey data matter: predicted niche of adult vs breeding Odonata. Freshw. Sci. 34: 1114-1122.

Samways, M.J. (2003). Threats to the tropical island dragonfly fauna (Odonata) of Mayotte, Comoro archipelago. Biodiv. Conserv. 12(9): 1785-1792.

Schorr, M. \& Paulson, D. (2017). World Odonata List. Slater Museum of Natural History, University of Puget Sound. https://www.pugetsound.edu/academics/academicresources/slater-museum/biodiversity-resources/dragonflies/world-odonata-list2. Accessed Sep. 2017.

Simaika, J.P. \& Samways, M.J. (2012). Using dragonflies to monitor and prioritize lotic systems: a South African perspective. Org. Divers. \& Evol. 12: 251-259.

Suh, A. N. \& Samways, M. J. (2001). Development of a dragonfly awareness trail in an African botanical garden. Biol. Conserv. 100: 345-353.

Tang, H.B., Wang, L.K. \& Hämäläinen, M. (2010). A photographic guide to the dragonflies of Singapore. Singapore: Raffles Museum of Biodiversity Research. 
Appendix 1. List of environmental variables recorded at sites for surveys of Odonata in Bukit Timah Nature Reserve, and the abbreviations used.

\begin{tabular}{|c|c|c|}
\hline Category & Description of parameter & Abbr. \\
\hline \multirow[t]{7}{*}{ Water parameters } & Acidity: Mean $\mathrm{pH}$ & PH \\
\hline & Mean Dissolved Oxygen (ppm) & DO \\
\hline & Mean Temperature & TEM \\
\hline & Mean Total Dissolved Solids (ppm) & TDS \\
\hline & Oxidation-Reduction Potential & ORP \\
\hline & Salinity & SAL \\
\hline & Flow Velocity & VEL \\
\hline \multirow[t]{3}{*}{ Stream dimension } & Mean Width (m) & WID \\
\hline & Mean Depth (cm) & DEP \\
\hline & Presence of Pool (0-3) & POL \\
\hline In-stream & Macrophyte and woody debris (\%) & MPW \\
\hline \multirow[t]{3}{*}{ Substrate } & Leaf litter $(\%)$ & LL \\
\hline & Sand $(\%)$ & SA \\
\hline & Silt (\%) & SI \\
\hline \multirow[t]{2}{*}{ Bank } & Shape (smooth 0- vertical 3) & BSH \\
\hline & Bank covered with shrub and grass (1-3) & BEV \\
\hline \multirow[t]{2}{*}{ Riparian } & vegetation heterogeneity $(0-3)$ & RHE \\
\hline & Canopy coverage (\%) & $\mathrm{RCA}$ \\
\hline \multirow[t]{3}{*}{ Connectivity } & Elevation & ELE \\
\hline & Forest edge $(0-3)$ & FE \\
\hline & Presence of swampy habitats $(0-3)$ & SW \\
\hline
\end{tabular}


Appendix 2. Abbreviations used for dragonfly species.

\begin{tabular}{|c|c|c|}
\hline Species & Common name & Abbreviation \\
\hline Amphicnemis gracilis & Will-o-wisp & Agr \\
\hline Anax guttatus & Emperor & $\mathrm{Agu}$ \\
\hline Agrionoptera sexlineata & Handsome Grenadier & Ase \\
\hline Brachydiplax chalybea & Blue Dasher & Bch \\
\hline Ceriagrion cerinorubellum & Ornate Coraltail & Cce \\
\hline Copera marginipes & Yellow Featherlegs & $\mathrm{Cma}$ \\
\hline Crocothemis servilia & Common Scarlet & Cse \\
\hline Devadatta argyoides & Malayan Grisette & Dar \\
\hline Drepanosticta quadrata & Singapore Shadowdamsel & Dqu \\
\hline Euphaea impar & Blue-sided Satinwing & Eim \\
\hline Epophthalmia vittigera & Pond Cruiser & Evi \\
\hline Hydrobasileus croceus & Water Monarch & Her \\
\hline Ictinogomphus decoratus & Common Flangetail & Ide \\
\hline Lathrecista asiatica & Scarlet Grenadier & Las \\
\hline Neurothemis fluctuans & Common Paraso & $\mathrm{Nfl}$ \\
\hline Nannophya pygmaea & Scarlet Pygmy & Npy \\
\hline Orthetrum chrysis & Spine-tufted Skimmer & Och \\
\hline Orthetrum glaucum & Common Blue Skimmer & $\mathrm{Ogl}$ \\
\hline Orthetrum luzonicum & Slender Blue Skimmer & Olu \\
\hline Orthertrum testaceum & Scarlet Skimmer & Ote \\
\hline Pseudagrion australasiae & Look-alike Sprite & $\mathrm{Pau}$ \\
\hline Prodasineura humeralis & Orange-striped Threadtail & $\mathrm{Phu}$ \\
\hline Pseudothemis jorina & Banded Skimmer & Pjo \\
\hline
\end{tabular}


Appendix 2. Continuation.

\begin{tabular}{lll}
\hline Species & Common name & Abbreviation \\
\hline Pseudagrion microcephalum & Blue Sprite & Pmi \\
Prodasineura notostigma & Crescent Threadtail & Pno \\
Podolestes orientalis & Blue-spotted Flatwing & Por \\
Rhyothemis obsolescens & Bronze Flutterer & Rob \\
Rhyothemis phyllis & Yellow-Barred Flutterer & Rph \\
Rhodothemis rufa & Common Redbolt & Rru \\
Rhythemis triangularis & Sapphire Flutterer & Rtr \\
Trithemis aurora & Crimson Dropwing & Tau \\
Trithemis festiva & Indigo Dropwing & Tfe \\
Tyriobapta torrida & Treehugger & Tto \\
Urothemis signata insignata & Scarlet Basker & Usi \\
Vestalis amethystina & Common Flashwing & Vam \\
\hline
\end{tabular}

